\title{
Effects of plasticizer and antifreeze on concrete at elevated temperatures and different cooling regimes
}

\author{
illknur Bekem Kara \\ Department of Construction, Borçka Acarlar Vocational High School, Artvin ÇoruhUniversity \\ 08400 Borçka, Artvin (Turkey) \\ ilknurbekem@artvin.edu.tr \\ https://orcid.org/0000-0001-9193-624X
}

\section{Metin Arslan}

Department of Real Estate Development and Management, Graduate School of Natural and Applied Sciences, Ankara University

06500 Beşevler, Ankara (Turkey)

metinarslan@ankara.edu.tr

https://orcid.org/0000-0002-5000-1226

Manuscript Code: 13874

Date of Acceptance/Reception: 04.12.2020/22.03.2020

DOI: 10.7764/RDLC.19.3.347

\begin{abstract}
In this study, the plasticizer and the antifreeze were used. The concrete specimens (the reference concrete without an admixture, concrete with plasticizer, concrete with antifreeze and concrete with plasticizer+antifreeze) were exposed to elevated temperatures (200, 400, 550 and 700 ㅇ) and cooling via air and water. Water absorption, ultrasonic pulse velocity and compressive strength tests were performed on the specimens. The concrete specimens were also analyzed using thermal gravimetric analysis and X-ray diffraction. The test results indicated that at the temperatures of 550 and $700 \stackrel{\circ}{ } \mathrm{C}$ and against both of the cooling regimes the plasticizer+antifreeze concrete showed a maximum strength loss. When the air cooled specimens were examined, the lowest strength loss was this obtained for reference concrete at 550 and $700 \stackrel{\circ}{ } \mathrm{C}$. The lowest strength loss at these temperatures for the water cooled specimens was observed in the concrete with antifreeze. According to thermal gravimetric analysis, the weight loss rate slightly decreases after $700{ }^{\circ} \mathrm{C}$. No portlandite peaks were observed in the concrete mixtures exposed to 700 을 and the cooling regimes was when they were compared at with the control specimens exposed to $20 \stackrel{\circ}{ } \mathrm{C}$ in the X-ray diffraction analysis.
\end{abstract}

Keywords: concrete, plasticizer, antifreeze, elevated temperatures, cooling regimes

Introduction

Fire poses a serious threat to the safety of structures. Structures can be both directly and indirectly exposed to high temperatures. The fire resistance parameter should not be ignored during the design of buildings. The choice of building materials has a very important role in the fire resistance of a building as the failure to demolish a building during a fire depends on the durability of the construction materials of the building. The most widely used material in the construction of structures all over the world is concrete. In this context, it is important to know the usual behavior of concrete and the behavior it displays during fires. The studies on the behavior of concrete against high temperatures are still ongoing (Papachristoforou et al., 2020; Mehdipour et al., 2020). When concrete is exposed to high temperatures, chemical changes occur in its structure, its physical properties become damaged and it losses strength. Thus, the effects of aggregate size and type, cement type and dosage, mineral admixtures, nano and fibrous materials on concrete at elevated temperatures and different cooling regimes have been widely investigated by several researchers (Karahan et al., 2019; Alharbi et al., 2020; Gökçe, 2019; Afzal \& Khushnood, 2020, Silva et al., 2020).

Chemical admixtures have become one of the main components of concrete alongside aggregate, cement and water. As an important part of concrete, different types of chemical admixtures have been widely used to improve its properties, such as good workability and high durability (Tong et al., 2020). One of the most commonly used admixtures is water reducing plasticizer. Plasticizers are admixtures that allow for the reduction of water in concrete without affecting its consistency or increase the slump without affecting the water content (TS EN 934-2, 2011). Antifreeze, on the other hand enables concrete to gain strength in cold weather by reducing the freezing point of the cement paste liquid phase and accelerating the hydration of the cement (Polat, 2016). The use of antifreeze is economical and common to reduce the negative impact of cold weather conditions on concrete (Khan \& Kumar, 2020). Concretes containing chemical admixtures can exhibit different behaviors compared to those without chemical admixtures when they are exposed to high temperatures (Maanser et al., 2018). Ahmad and Abdulkareem (2010) determined that admixtures can be considered as one of the factors that affect the heat-treatment of concrete with other factors. There 
are very few studies on the effects of chemical admixtures at elevated temperatures. Some researches regarding the topic are summarized below:

Aruntas et al. (2009) investigated the effect of superplasticizers on concrete at high temperatures. In their study, the reference concrete and concrete with superplasticizer were exposed to 20, 100, 200, 300, 400, 500 and 700 으. They determined that the compressive strength of the concrete without an admixture decreased by $50 \%$ at $400{ }^{\circ} \mathrm{C}$ and $72 \%$ at $700{ }^{\circ} \mathrm{C}$, while the compressive strength of the concrete with the superplasticizer decreased by $42 \%$ at $400{ }^{\circ} \mathrm{C}$ and $78 \%$ at $700{ }^{\circ} \mathrm{C}$.

In another study conducted by Ahmad and Abdulkareem (2010), concrete mixtures containing super plasticizer, plasticizer, retarding and water reducing admixture, accelerating admixture, air entrainers were exposed to 200,400

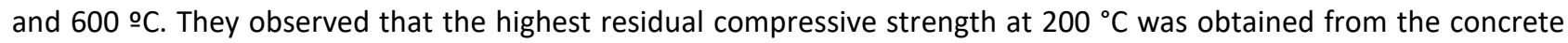
with plasticizer. The highest residual compressive strength 400 and $600{ }^{\circ} \mathrm{C}$, on the other hand, were obtained from the concrete containing the retarding and water reducing admixture.

Regardless of the chemical admixture type, concrete are exposed to high temperature effects during fire. According to the literature review, there was no study conducted on the strengths of concrete containing antifreeze after being exposed to high temperatures and different cooling regimes. Thus, in this study, plasticizer and antifreeze were preferred and were used to prepare four concrete mixtures. The influence of different chemical admixtures on the development of the high temperature strength with cooling regimes was studied and compared.

Experimental program

\section{Materials}

CEM I 42.5 R Portland cement conforming to EN 197-1 (2012) standard was used for all of the mixtures in the study. The cement's specific fineness was $3320 \mathrm{~cm}^{2} / \mathrm{g}$. Water conforming to EN 1008 (2013) requirements was used in the concrete mixtures. The water was potable and did not contain any harmful substances. The maximum grain size of the limestone aggregates was $16 \mathrm{~mm}$. The specific gravities of aggregates are 2.72 for $0-4$ and $4-8 \mathrm{~mm} ; 2.74$ for 8-16 mm. Water absorption results of the aggregates are $1.43 \%, 0.96 \%$ and $0.74 \%$ (TS EN 1097-6, 2013).

Two types of well-known commercial admixtures, namely inorganic salt-based antifreeze and lignin sulfonatebased plasticizer, were used in this study (ASTM C494, 2016; TS EN 934-2, 2011). The pH value of the antifreeze was 6.00 and its solution density was $1250 \mathrm{~kg} / \mathrm{m}^{3}$. The $\mathrm{pH}$ value of plasticizer, on the other hand, was 6.50 and its solution density was $1060 \mathrm{~kg} / \mathrm{m}^{3}$.

\section{Methods}

The concrete mixture for the experimental investigations were prepared according to the TS 802 (2016) and TS EN 2061 (2017) standards. The concrete class of the specimens was C30/37. The plasticizer and the antifreeze were used at $1 \%$ rate of the cement weight. The admixtures were added into the mixing water. The mixture proportions for $1 \mathrm{~m}^{3}$ concrete are given in Table 1. In this study, four concrete mixtures were produced. The mixtures were coded as ref for the concrete without an admixture, $P$ for the concrete with plasticizer, $A$ for the concrete with antifreeze and PA for the concrete with plasticizer+antifreeze. In concrete mixtures, W/C are different in order to keep the slump values equal.

Table 1. The mixture proportions for $1 \mathrm{~m}^{3}$ concrete.

\begin{tabular}{|c|c|c|c|c|c|c|c|c|}
\hline \multirow{3}{*}{$\begin{array}{l}\text { Concrete } \\
\text { mixtures }\end{array}$} & \multirow{3}{*}{$\begin{array}{l}\mathrm{W} / \mathrm{C} \\
\text { ratio }\end{array}$} & \multicolumn{7}{|c|}{ Materials } \\
\hline & & \multirow{2}{*}{$\begin{array}{c}\text { Cement } \\
(\mathrm{kg})\end{array}$} & \multirow{2}{*}{$\begin{array}{l}\text { Water } \\
\text { (I) }\end{array}$} & \multirow{2}{*}{$\begin{array}{c}\text { Plasticizer } \\
\text { (I) }\end{array}$} & \multirow{2}{*}{$\begin{array}{c}\text { Antifreeze } \\
\text { (I) }\end{array}$} & \multicolumn{3}{|c|}{ Aggregate (kg) } \\
\hline & & & & & & $0-4 \mathrm{~mm}$ & $4-8 \mathrm{~mm}$ & $8-16 \mathrm{~mm}$ \\
\hline Ref & 0.60 & 350 & 210 & 0 & 0 & 908 & 544 & 368 \\
\hline$P$ & 0.55 & 350 & 193 & 3.5 & 0 & 922 & 552 & 370 \\
\hline$A$ & 0.59 & 350 & 207 & 0 & 3.5 & 917 & 550 & 370 \\
\hline PA & 0.53 & 350 & 187.5 & 3.5 & 3.5 & 939 & 564 & 380 \\
\hline
\end{tabular}


Firstly, cement and both fine and coarse aggregate were placed in a laboratory mixer and mixed for $1.5-2$ min. Then the admixtures were added into water. After the water was added to the mix, all of materials were mixed for 3-3.5 min. (TS EN 12390-2, 2010). Slump test was carried out in fresh concrete (TS EN 12350-2, 2010). The average value of the slump was $11 \mathrm{~cm}$ for the concrete mixtures. Fresh concrete both with and without the admixtures were cast into $15 \times 50 \times 60 \mathrm{~cm}$ plate molds (TS 1247, 2018). Three molds were used for each concrete type. The cylindrical core specimens were extracted from these molds on the $14^{\text {th }}$ day (TS EN 12504-1, 2011). In this study, total 600 core specimens were taken from the concrete slabs to obtain a better representation of the material. The top and bottom of the core specimens were cut. The diameter of the cylinder samples was $50 \mathrm{~mm}$ and the height was $100 \mathrm{~mm}$. They were kept in the water cure pool until the $90^{\text {th }}$ day at $20 \pm 2{ }^{\circ} \mathrm{C}$.

After 90 days of water cure, concrete specimens were dried at $100 \pm 5^{\circ} \mathrm{C}$ for $24 \mathrm{~h}$ in an oven to remove the excess water. 150 specimens of each concrete mixture were used. Then the concrete specimens were thermally treated in an oven at $200,400,550$ and $700^{\circ} \mathrm{C}$ for 3 hours to evaluate the effect of the elevated temperatures, 30 specimens of each temperature were used. Then, half of the specimens were cooled at an ambient temperature $(20 \stackrel{\circ}{\circ})$ while the other half were cooled with water.

Water absorption was performed according to ASTM C642 (2004) principles, ultrasonic pulse velocity (UPV) according to ASTM C 597-83 (2016) principles and compressive strength tests according to EN 12390-3 (2010) principles on $\varnothing 50 \times 100 \mathrm{~mm}$ cylindrical concrete specimens after the heating and cooling processes. Test results were compared with the control specimens which were stored in laboratory conditions after drying at $100 \pm 5{ }^{\circ} \mathrm{C}$.

The thermal analysis test is a technique that determines the change in the weight of the sample due to the temperature increase. It was performed with a PERKIN ELMER STA-600 device. A $15 \mathrm{mg}$ weight is placed on the thermonanobalance of the apparatus and weighted accurately throughout the test. The powder samples were heated from $20^{\circ} \mathrm{C}$ to $900{ }^{\circ} \mathrm{C}$ with a $20^{\circ} \mathrm{C}$ per minute heating rate. The thermogravimetric curve (TGA) and the derived thermogravimetric curve (DTG) were obtained on four concrete type.

XRD allows the qualitative and quantitative chemical identification of the crystalline phases found in the material at high temperatures (Caetano et al., 2019). Core specimens stored at 20 ㅇ C and exposed 700 ㅇ C were crushed and milled for standard qualitative mineral analysis by XRD method. The diffraction patterns of the samples were obtained at room temperature, in the X-pert Pro model powder diffractometer system of Panalytical brand and by using copper radiation $\left[\lambda(\mathrm{CuK} \alpha)=1.54056 \AA\right.$ ] between $2^{\circ}$ and $70^{\circ}$ theta screening range.

The methods used in the study are shown in Figure 1.

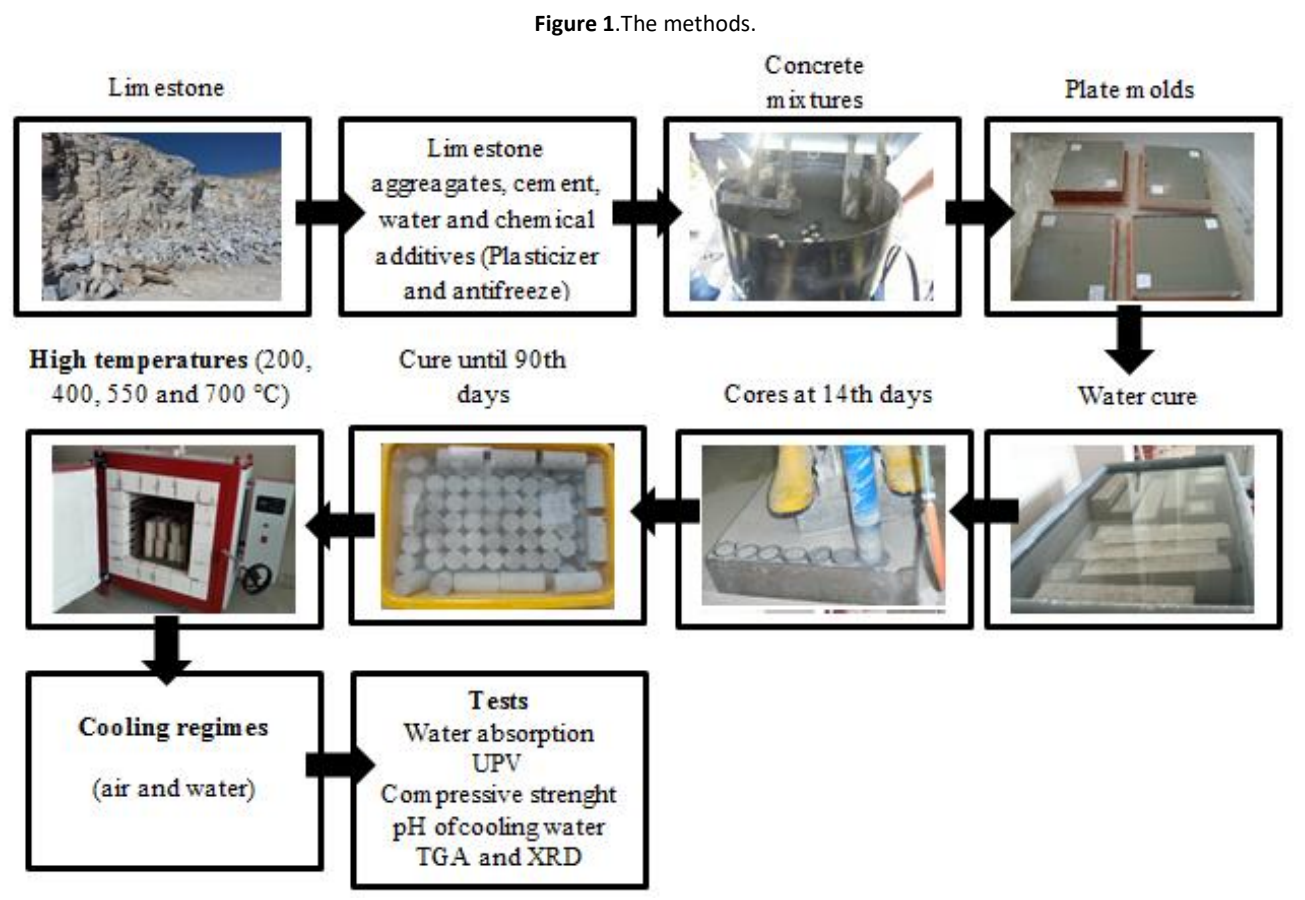




\section{Water absorption capacities}

The $90^{\text {th }}$ day water absorption results of the concrete mixtures exposed to the heating and cooling regimes are exhibited in Figure 1. Figure 1 displays an overview of the effect of the elevated temperatures on the water absorption capacities of the concrete mixtures compared to the control mixture, which was exposed to $20^{\circ} \mathrm{C}$. After being heated to 200 o $\mathrm{C}$ and then cooled via water cooling the water absorption properties of the ref, $\mathrm{P}$ and PA mixtures decreased. The most significant reduction was observed in the $\mathrm{P}$ mixture. The water absorption capacity of the water cooled $\mathrm{P}$ specimens decreased from $4.78 \%$ to $3.76 \%$ at $200{ }^{\circ} \mathrm{C}$. Water absorption was significantly influenced by the cooling regimes at 550 and $700{ }^{\circ} \mathrm{C}$ for the ref, $\mathrm{P}$ and $\mathrm{A}$ mixtures. The cooling regime did not create a large difference in the PA mixture. The water absorption capacity of concrete generally increases with the increase in temperature. It is also known that pores and micro cracks in concrete increase as a result of high temperature exposure. This has a great impact on the water absorption capacity of concrete (Hiremath and Yaragal, 2018). The water absorption capacities of the air-cooled specimens were greater than the water cooled specimens for all of the mixtures. In this context, it can be said that air cooling causes more pores and micro cracks.

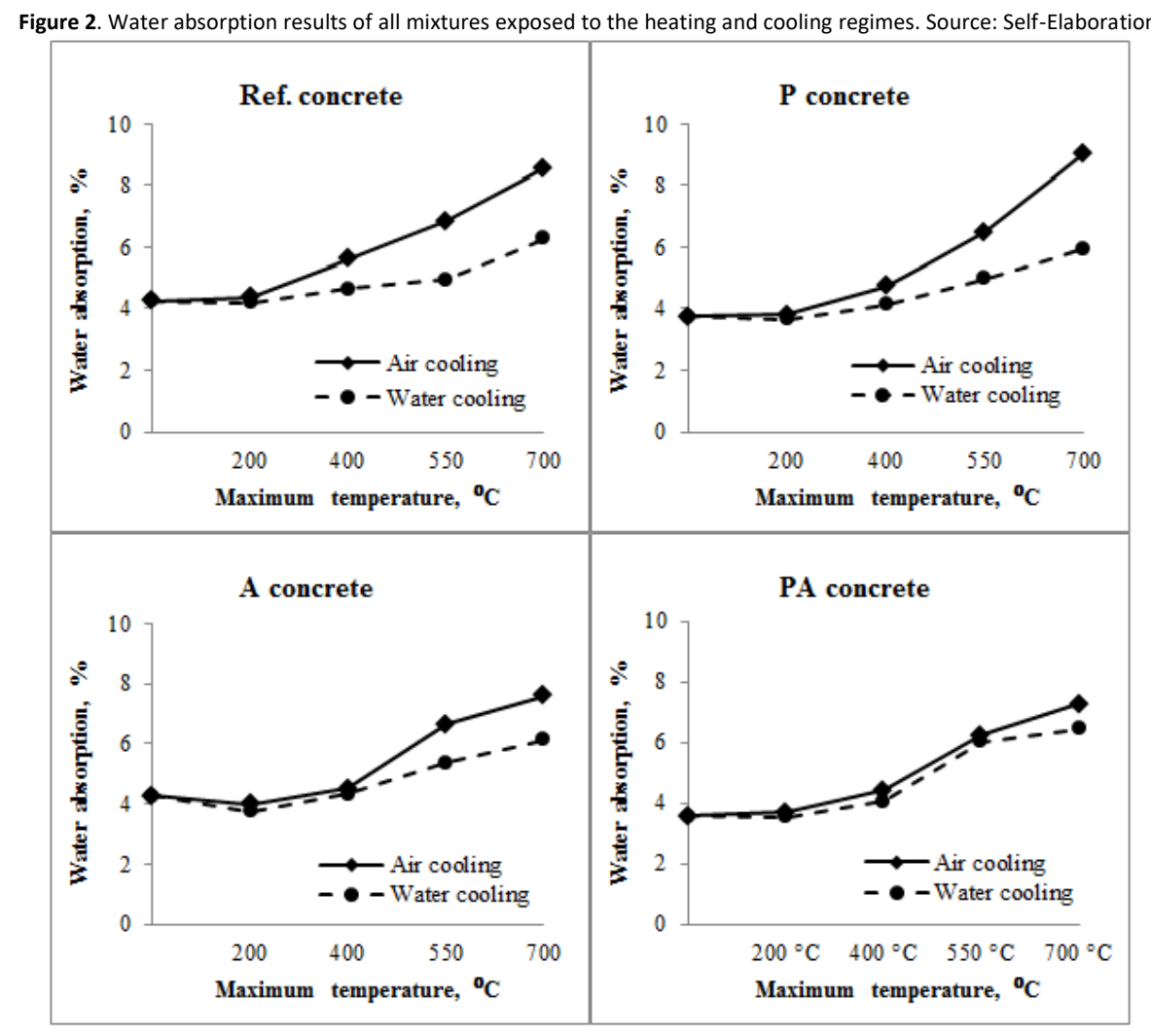

In Table 2, the differences in the water absorption capacities of the concrete mixtures exposed to elevated temperatures and cooling regimes can be seen. When the temperature reached 550 and $700 \circ \mathrm{C}$, the water absorption capacities of the air cooled samples increased rapidly. It is thought that this may cause the occurrence of excessive voids due to the dehydration of C-S-H gel (Salahuddin et al., 2019).

Table 2. The effect of high temperature and the cooling regimes on the difference of water absorption ( $\downarrow$ : decrease, $\uparrow:$ increase). Source: Self-Elaboration

\begin{tabular}{|c|c|c|c|c|c|c|c|c|c|}
\hline \multicolumn{10}{|c|}{ Difference of Water adsorption, \% } \\
\hline \multirow{2}{*}{\multicolumn{2}{|c|}{$\begin{array}{l}\text { Temperature, }{ }^{\circ} \mathrm{C} \\
\text { Cooling regime }\end{array}$}} & 200 & 400 & 550 & 700 & 200 & 400 & 550 & 700 \\
\hline & & \multicolumn{4}{|c|}{ Air cooling } & \multicolumn{4}{|c|}{ Water cooling } \\
\hline \multirow{4}{*}{$\begin{array}{l}\text { Concrete } \\
\text { type }\end{array}$} & Ref & $\downarrow 0.81$ & 个15.68 & $\uparrow 33.83$ & 个56.35 & $\downarrow 2.33$ & 个5.10 & 个5.44 & 个25.54 \\
\hline & $\mathrm{P}$ & 个1.04 & 个19.47 & $\uparrow 35.28$ & $\uparrow 72.00$ & 个2.14 & 个7.37 & 个12.24 & $\uparrow 27.71$ \\
\hline & A & $\downarrow 4.77$ & 个3.88 & $\uparrow 32.69$ & 个45.33 & $\downarrow 7.15$ & $\uparrow 0.41$ & 个14.84 & $\uparrow 25.55$ \\
\hline & PA & 个4.92 & 个16.95 & $\uparrow 43.18$ & 个54.55 & $\uparrow 2.20$ & 个16.17 & $\uparrow 25.74$ & 个38.13 \\
\hline
\end{tabular}


UPV test is a qualitative test used to evaluate the quality of concrete. It is a technique that is sensitive to degradation phenomena including internal cracking and other deterioration due to thermal treatment (Hiremath and Yaragal, 2018). The UPV of the specimens were measured on the $90^{\text {th }}$ day. The minimum UPV value was obtained from the A concrete mixture as 3.56, while the maximum UPV value was obtained for the PA concrete mixture as $3.78 \mathrm{~km} / \mathrm{s}$. The UPV test was carried out once again after the specimens were exposed to the high temperatures and the cooling regimes. However, the UPV values of the specimens subjected to the air cooling regime could not be measured at 550 and 700 ${ }^{\circ} \mathrm{C}$. As is known, ultrasonic gel is applied to the surfaces where the receiver and transmitter tips are applied in the measurement of UPV. Therefore, with this gel, a curtain against air is formed between the ends and the concrete surface. These specimens have cracks on the surface (Figure 3). The UPV device did not measure due to mutual air passage or the formation of gaps, due to cracks around the cylinder. Therefore, the results for the specimens exposed 550 and $700{ }^{\circ} \mathrm{C}$ and air cooling are missing in Figure 4. The results for the UPV test conducted on the $90^{\text {th }}$ day for the concrete mixtures exposed to the high temperatures and cooling regimes are exhibited in Figure 4.

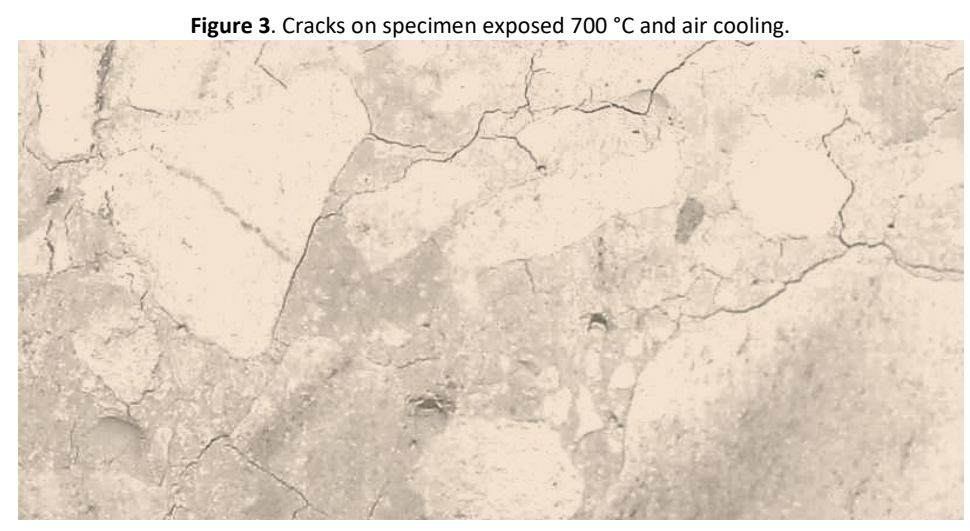

At $200 \stackrel{\circ}{ } \mathrm{C}$, the results for the air cooled specimens varied between 3.39 and $3.66 \mathrm{~km} / \mathrm{s}$, while the results for the water cooled specimens varied between $3.27-3.46 \mathrm{~km} / \mathrm{s}$. At $400 \stackrel{\circ}{\circ}$, these results ranged between $1.77-2.33 \mathrm{~km} / \mathrm{s}$ and $1.92-$ $2.19 \mathrm{~km} / \mathrm{s}$ for the air and water cooled specimens, respectively. At 550 and $700{ }^{\circ} \mathrm{C}$, the results varied between 1.32 and $1.48 \mathrm{~km} / \mathrm{s}$ for the air cooled specimens and $1.00-1.25 \mathrm{~km} / \mathrm{s}$ for for the water cooled specimens. It is known that there is a relationship between mechanical properties and UPV results as UPV results depend on pore structure and specimen density (Benaicha et al., 2015). It was thought that the pores of the air cooled samples were more than those of the

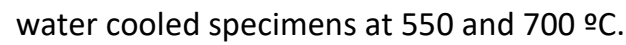

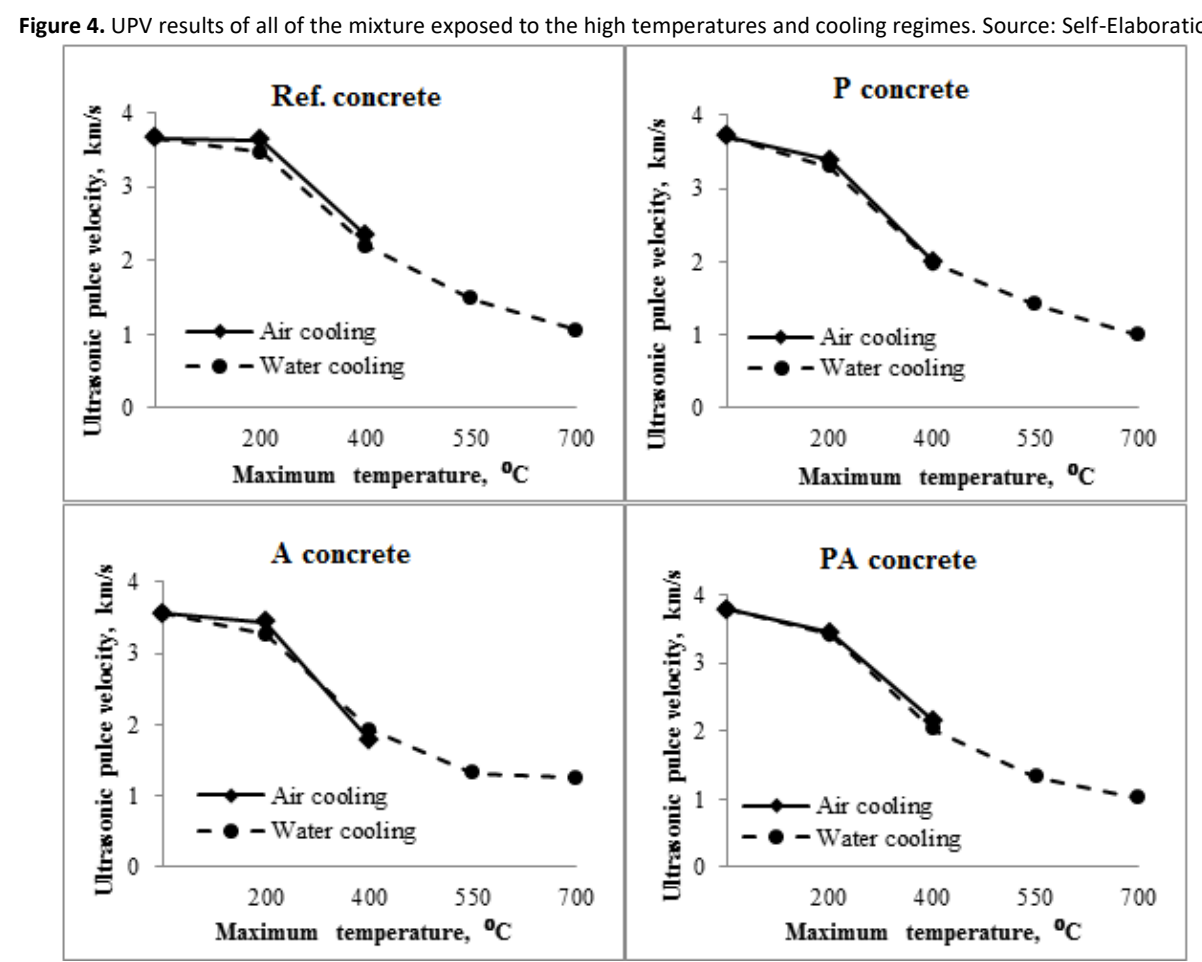


Table 4 shows the decrease in the UPV values after the exposure to the high temperatures and the cooling regimes. As the temperature increased, the UPV values of the air cooled ref, $\mathrm{P}, \mathrm{A}$ and PA concrete mixtures reduced by $0.82 \%, 8.87 \%$, $3.37 \%$ and $8.73 \%$ at $200{ }^{\circ} \mathrm{C}$, respectively. These results increased to $36.34 \%, 46.24 \%, 50.28 \%$ and $46.30 \% \mathrm{~km} / \mathrm{s}$ for 400 oc, respectively

It was determined that the water cooled specimens showed a higher decrease in UPV values at 200 and $400^{\circ} \mathrm{C}$ compared to the air cooled specimens. After being heated to $550 \circ \mathrm{C}$, the UPV values of the water-cooled ref., P, A and PA concrete mixtures reduced by $59.56 \%, 61.83 \%, 62.92 \%$ and $65.08 \%$, respectively. It is known that micro cracks in the cement paste and aggregates begin to spread between 450-600 ㄷ. Thus, the UPV results showed a decrease of more than $50 \%$ (AzariJafari et al., 2019). The minimum UPV decrease at $700^{\circ} \mathrm{C}$ was observed in the water cooled $\mathrm{A}$ concrete mixture as $64.89 \%$, while the maximum UPV decrease was observed in the water cooled PA concrete mixture as $73.28 \%$ at 700 ㅇ. .

Table 4. Decreases in the UPV values of the concrete specimens after being exposed to the high temperatures and cooling regimes ( $\downarrow$ : decrease). Source: SelfElaboration.

\begin{tabular}{|c|c|c|c|c|c|c|c|c|c|}
\hline \multicolumn{10}{|c|}{ Difference of UPV, \% } \\
\hline \multicolumn{2}{|c|}{ Temperature, ${ }^{\circ} \mathrm{C}$} & 200 & 400 & 550 & 700 & 200 & 400 & 550 & 700 \\
\hline \multicolumn{2}{|c|}{ Cooling regime } & \multicolumn{4}{|c|}{ Air cooling } & \multicolumn{4}{|c|}{ Water cooling } \\
\hline \multirow{4}{*}{$\begin{array}{l}\text { Concrete } \\
\text { type }\end{array}$} & Ref & $\downarrow 0.82$ & $\downarrow 36.34$ & $\downarrow 100.00$ & $\downarrow 100.00$ & $\downarrow 5.46$ & $\downarrow 40.16$ & $\downarrow 59.56$ & $\downarrow 71.31$ \\
\hline & $P$ & $\downarrow 8.87$ & $\downarrow 46.24$ & $\downarrow 100.00$ & $\downarrow 100.00$ & $\downarrow 11.29$ & $\downarrow 47.04$ & $\downarrow 61.83$ & $\downarrow 73.12$ \\
\hline & $\mathrm{A}$ & $\downarrow 3.37$ & $\downarrow 50.28$ & $\downarrow 100.00$ & $\downarrow 100.00$ & $\downarrow 8.15$ & $\downarrow 46.07$ & $\downarrow 62.92$ & $\downarrow 64.89$ \\
\hline & PA & $\downarrow 8.73$ & $\downarrow 46.30$ & $\downarrow 100.00$ & $\downarrow 100.00$ & $\downarrow 9.52$ & $\downarrow 46.30$ & $\downarrow 65.08$ & $\downarrow 73.28$ \\
\hline
\end{tabular}

\section{Compressive strength}

The compressive strength values of the concrete specimens after being exposed to the high temperatures and cooling regimes are shown in Figure 5. The compressive strengths of all of the concrete mixtures reduced rapidly after being exposed to $400 \stackrel{\circ}{ } \mathrm{C}$. A further reduction in the compressive strengths of the water cooled specimens was observed at 200 and $400{ }^{\circ} \mathrm{C}$ compared to the air cooled ones. This finding was in parallel with those in the literature. Wang et al. (2019) reported that strength deterioration was more severe for concrete samples subjected to water cooling compared to those subjected to natural cooling, especially at the temperatures of 200 and $400{ }^{\circ} \mathrm{C}$. However, the opposite of this situation occurred as the temperatures increased. The air cooled specimens were more damaged than the water cooled ones at 550 and 700 ․ C. The reason for this is that cement mortar decomposes at high temperatures, however, when water cooling is carried out, the components are re-hydrated. The air cooled specimens were found to be denser than the water cooled specimens. It is known that cooling regimes have an effect on residual compressive strength (Luo et al., 2010). Durgun and Sevinc (2019) reported that air cooled specimens were more exposed to atmospheric conditions. In such cases, $\mathrm{CaO}$ produced by $\mathrm{CaCO}_{3}$ decomposition is recycled and volume expansion occurs. According to Karakoç (2013), in actual situations fires in buildings are extinguished using water. However, there are very few studies that have been conducted on cooling regimes.

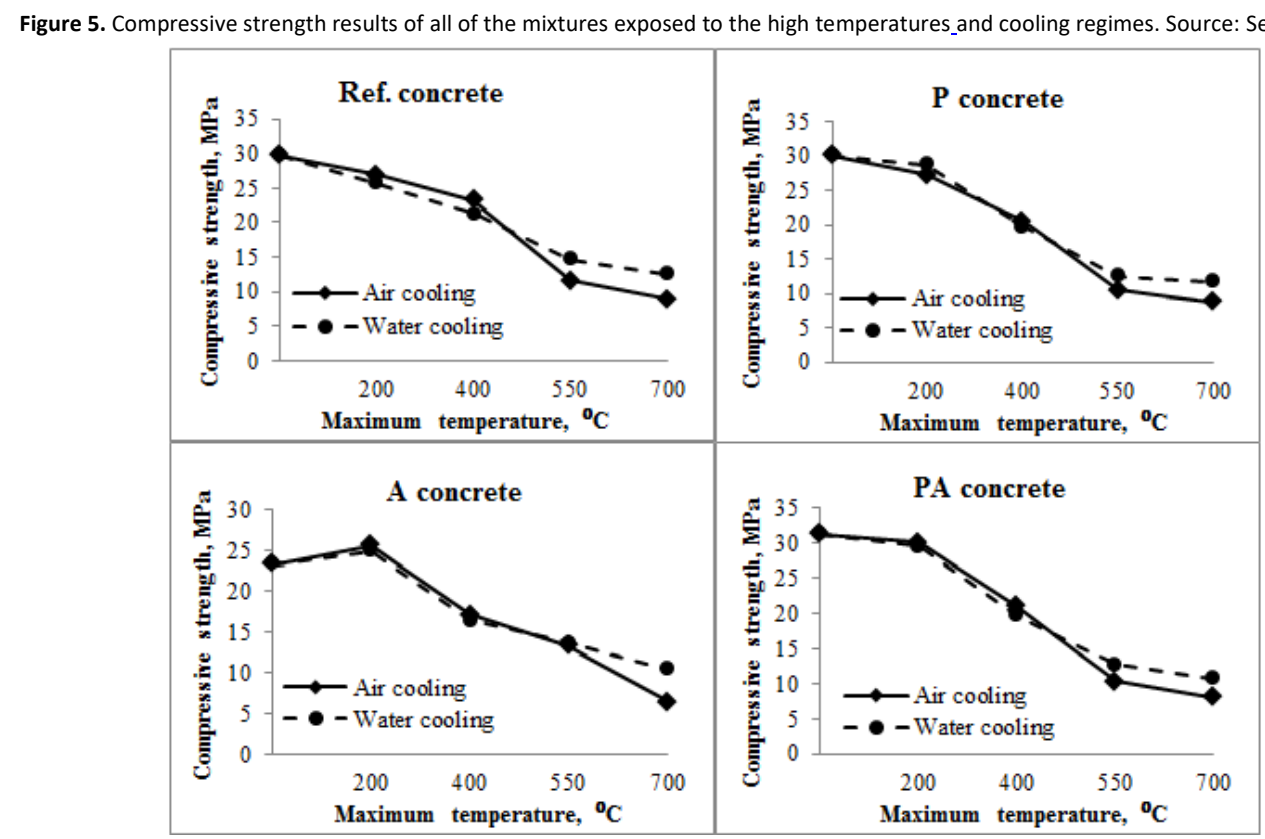


The specimens of each concrete type that had been kept at 20 o $\mathrm{C}$ were accepted as the control specimens and their compressive strengths were accepted as $100 \%$. The differences in the compressive strengths of the specimens were calculated by using the control strengths and the strengths obtained after the specimens were exposed to the high temperatures (Table 5).

Table 5. The effect of the high temperatures on the compressive strength ( $\downarrow$ : decrease, $\uparrow:$ increase). Source: Self-Elaboration.

\begin{tabular}{|c|c|c|c|c|c|c|c|c|c|}
\hline \multicolumn{10}{|c|}{ Difference of strenght, \% } \\
\hline \multirow{2}{*}{\multicolumn{2}{|c|}{$\frac{\text { Temperature, }{ }^{\circ} \mathrm{C}}{\text { Cooling regime }}$}} & 200 & 400 & 550 & 700 & 200 & 400 & 550 & 700 \\
\hline & & \multicolumn{4}{|c|}{ Air cooling } & \multicolumn{4}{|c|}{ Water cooling } \\
\hline \multirow{4}{*}{$\begin{array}{l}\text { Concrete } \\
\text { type }\end{array}$} & Ref & $\downarrow 9.13$ & $\downarrow 21.71$ & $\downarrow 60.94$ & $\downarrow 70.21$ & $\downarrow 13.18$ & $\downarrow 28.24$ & $\downarrow 50.62$ & $\downarrow 57.80$ \\
\hline & $P$ & $\downarrow 9.47$ & $\downarrow 31.85$ & $\downarrow 64.93$ & $\downarrow 71.07$ & $\downarrow 4.78$ & $\downarrow 34.77$ & $\downarrow 58.45$ & $\downarrow 61.04$ \\
\hline & A & 个9.61 & $\downarrow 26.94$ & $\downarrow 42.74$ & $\downarrow 72.50$ & 个6.62 & $\downarrow 29.97$ & $\downarrow 41.72$ & $\downarrow 55.51$ \\
\hline & PA & $\downarrow 3.54$ & $\downarrow 32.84$ & $\downarrow 66.92$ & $\downarrow 74.41$ & $\downarrow 5.39$ & $\downarrow 37.02$ & $\downarrow 59.69$ & $\downarrow 65.74$ \\
\hline
\end{tabular}

At $200^{\circ} \mathrm{C}$, the compressive strengths of the ref, P and PA mixtures decreased in both the air and water cooled specimens. However, the compressive strength of the A concrete mixture increased in both cooling conditions. The increase in compressive strength between the temperature range of $105-200{ }^{\circ} \mathrm{C}$ can be explained by the further hydration of dehydrated cement particles and/or an improvement of the local mechanical properties of C-S-H (Lim and Mondal, 2015). Previous studies determined that the cause of this phenomenon is the thermal expansion stress generated in concrete due to heating (Hwang et al., 2018).

Air cooling at 400 ㅇ caused the compressive strength of the specimens to decrease in the range of $21.71-32.84 \%$, while this range was $28.24-37.02 \%$ for water cooling at the same temperature. The compressive strengths of the air cooled specimens exposed to 550 oC decreased in the ranges of $42.74-66.92 \%$. This range was between $41.72 \%$ and $59.69 \%$ for the water cooled specimens at the same temperature. It is known that when concrete is exposed to a temperature above $400 \stackrel{\circ}{ } \mathrm{C}$, the $\mathrm{Ca}(\mathrm{OH})_{2}$ in the concrete begins to dehydrate and compressive strength decreases by $45 \%$ (Dexing et al., 2018). At $700 \stackrel{\circ}{ } \mathrm{C}$, the decrease in compressive strength was higher for the air cooled specimens compared to the water cooled specimens. The decrease in compressive strength of the air cooled specimens exceeded $70.00 \%$ for all of the mixtures. The decreases in the compressive strength of the water-cooled specimens, on the other hand, were in the ranges of $55.51-65.74 \%$ at the same temperature. It is known that after $550{ }^{\circ} \mathrm{C}$, as almost all $\mathrm{C}$-S- $\mathrm{H}$ gel and $\mathrm{Ca}(\mathrm{OH})_{2}$ crystals decompose and the internal structure of concrete is further damaged and cracked, the compressive strength further decreases (Wang et al., 2017).

\section{Properties of the cooling water}

The following were observed when the $\mathrm{pH}$ changes of the cooling water after high temperature application were examined (Table 6):

- Increased cooling water $\mathrm{pH}$ with the increase in temperature.

- The $\mathrm{pH}$ value of the cooling water of PA at $700^{\circ} \mathrm{C}$ was 8.62 , however this value changed to 10.22 after the cooling process.

It is thought that the increase in the $\mathrm{pH}$ value according to the increase in temperature occurred due to some of the $\mathrm{CaO}$ dissolving in water and converting into $\mathrm{Ca}(\mathrm{OH})_{2}$.

\begin{tabular}{|c|l|c|c|c|c|}
\hline \multirow{2}{*}{ Temperature, ${ }^{\circ} \mathrm{C} . \mathrm{pH}$ values of the cooling water } \\
\cline { 3 - 6 } & \multicolumn{2}{|c}{$\mathrm{pH}$ of water } & \multicolumn{4}{c|}{ Concrete mixtures } \\
\cline { 3 - 6 } & & Ref & $\mathrm{P}$ & $\mathrm{A}$ & $\mathrm{PA}$ \\
\hline \multirow{2}{*}{200} & Before cooling & 8.08 & 8.12 & 8.30 & 8.45 \\
\cline { 2 - 6 } & After cooling & 8.14 & 8.26 & 8.42 & 8.66 \\
\hline \multirow{2}{*}{400} & Before cooling & 8.24 & 8.28 & 8.26 & 8.45 \\
\cline { 2 - 6 } & After cooling & 8.38 & 8.42 & 8.41 & 8.68 \\
\hline \multirow{2}{*}{550} & Before cooling & 8.41 & 8.29 & 8.37 & 8.54 \\
\cline { 2 - 6 } & After cooling & 8.48 & 8.39 & 8.65 & 8.88 \\
\hline \multirow{2}{*}{700} & Before cooling & 8.42 & 8.47 & 8.53 & 8.62 \\
\cline { 2 - 6 } & After cooling & 9.42 & 9.46 & 9.44 & 10.22 \\
\hline
\end{tabular}


The $\mathrm{pH}$ of the cooling water changed the most in the PA concrete mixture. This was in parallel with the decrease in compressive strength. The concrete mixture that lost the most compressive strength at 400,550 and $700{ }^{\circ} \mathrm{C}$ the PA concrete mixture. It was determined that the concrete type most prone to being damaged from temperature and cooling conditions had the cooling water with the highest $\mathrm{pH}$ difference.

\section{Thermo gravimetric analysis}

TGA/DTG curves are presented in Figure 6. The weight loss at $200{ }^{\circ} \mathrm{C}$ is $1.59 \%, 1.61 \%, 1.16 \%$ and $1.60 \%$ for Ref., $P, A$ and PA concrete, respectively. The weight loss at $400{ }^{\circ} \mathrm{C}$ is $2.66 \%, 2.61 \%, 2.36 \%$ and $2.03 \%$ for Ref., P, A and PA concrete, respectively. The weight loss at $550{ }^{\circ} \mathrm{C}$ is $3.90 \%, 4.13 \%, 3.50 \%$ and $2.89 \%$ for Ref., $\mathrm{P}, \mathrm{A}$ and PA concrete, respectively. The weight loss at $700{ }^{\circ} \mathrm{C}$ is $6.01 \%, 6.67 \%, 6.42 \%$ and $5.72 \%$ for Ref., P, A and PA concrete, respectively. The weight loss rate slightly decreases after $700{ }^{\circ} \mathrm{C}$. The decomposition process starts at $760{ }^{\circ} \mathrm{C}$ and finishes abruptly at $846^{\circ} \mathrm{C}$ for Ref. concrete. It starts at $761{ }^{\circ} \mathrm{C}$ and finishes $831^{\circ} \mathrm{C}$ for $\mathrm{P}$ concrete. It starts at $768^{\circ} \mathrm{C}$ and finishes $831^{\circ} \mathrm{C}$ for $\mathrm{A}$ concrete. It starts at $790{ }^{\circ} \mathrm{C}$ and finishes $850{ }^{\circ} \mathrm{C}$ for PA concrete.

Total weight loss is about $39 \%, 40 \%, 41 \%$ and $42 \%$ for Ref., P, A and PA concrete, respectively. The peaks result from water evaporation (a), decomposition of portlandite at $400-500{ }^{\circ} \mathrm{C}(\mathrm{b})$ and decomposition of calcium carbonate between 700 and $850^{\circ} \mathrm{C}(\mathrm{c})$ in Figure 6.

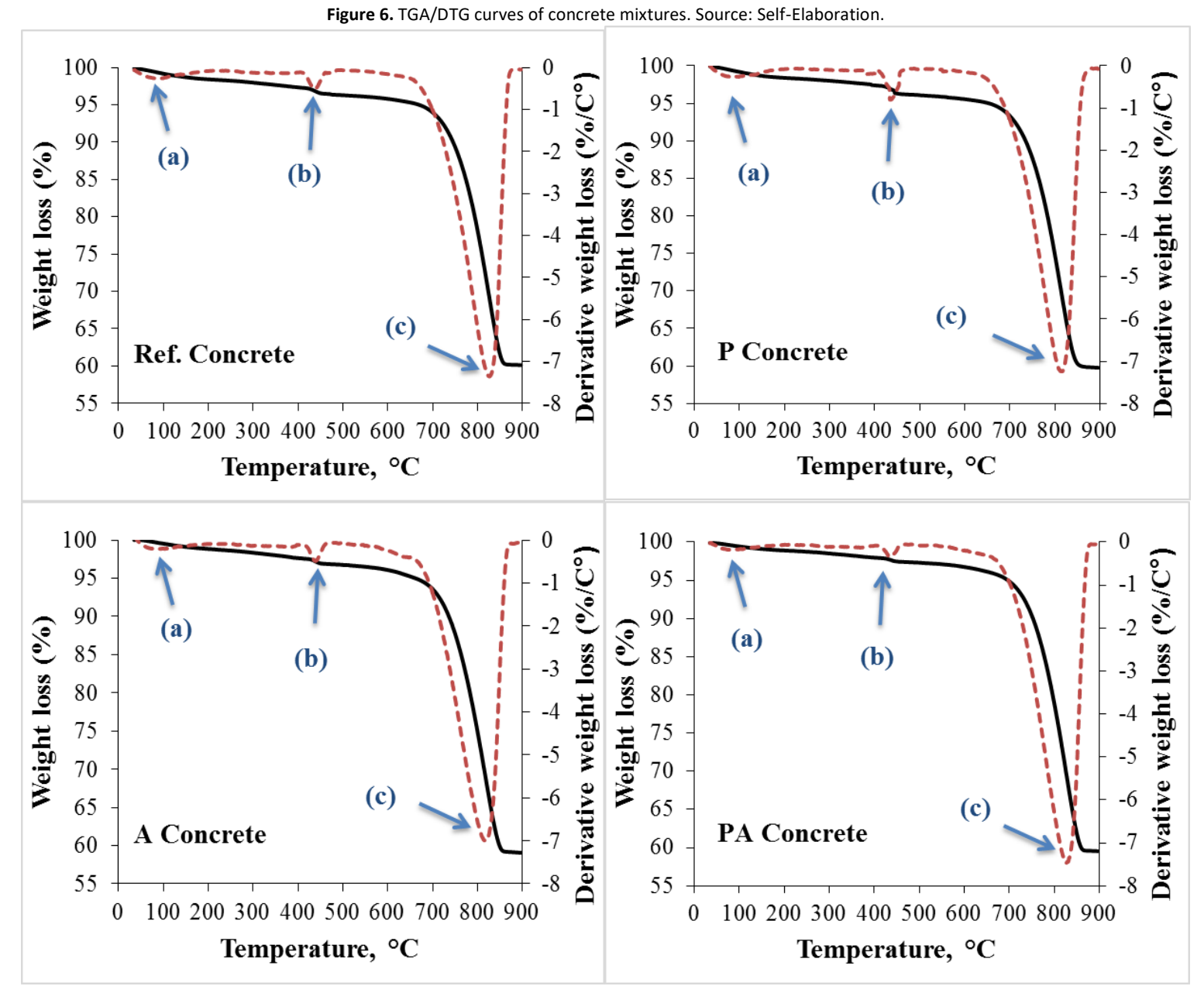

\section{X-ray diffraction analysis}

XRD analysis was used to determine the changes in the mineralogical structures of the concrete types after being exposed to $700{ }^{\circ} \mathrm{C}$ and the cooling regimes. Figure 7 shows the diffraction patterns of the concrete mixtures. 
Figure 7. XRD pattern of the detached concrete pieces from the specimens (P: Portlandite, C: Calcite, Q: Quartz) and the portlandite detail. Source: Self-Elaboration.

Ref. concrete

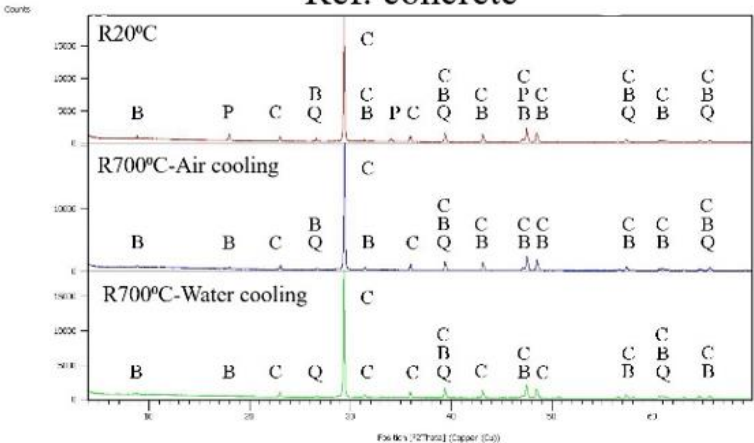

P concrete
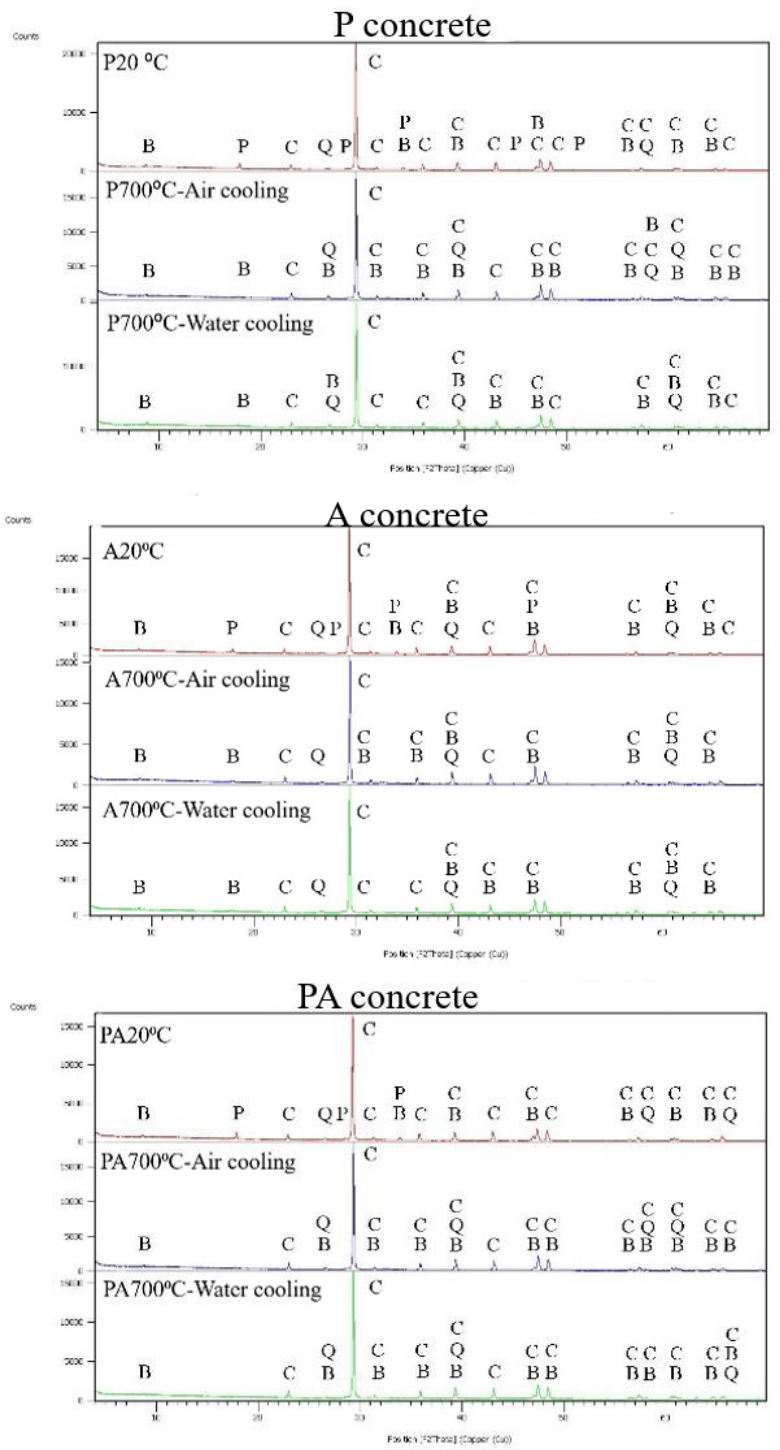

Portlandite detail

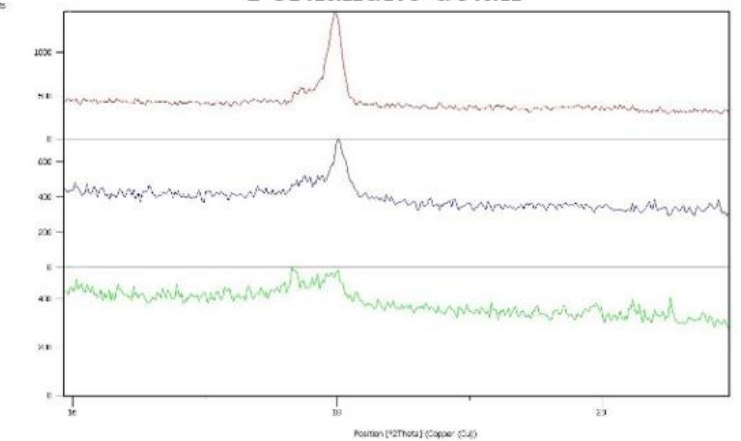

Portlandite detail

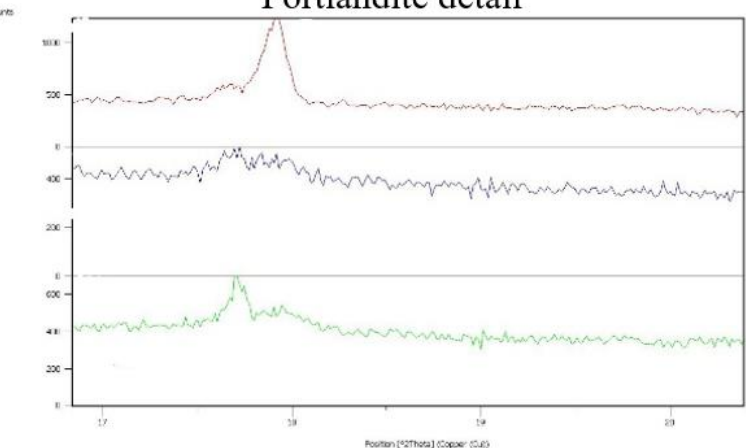

Portlandite detail
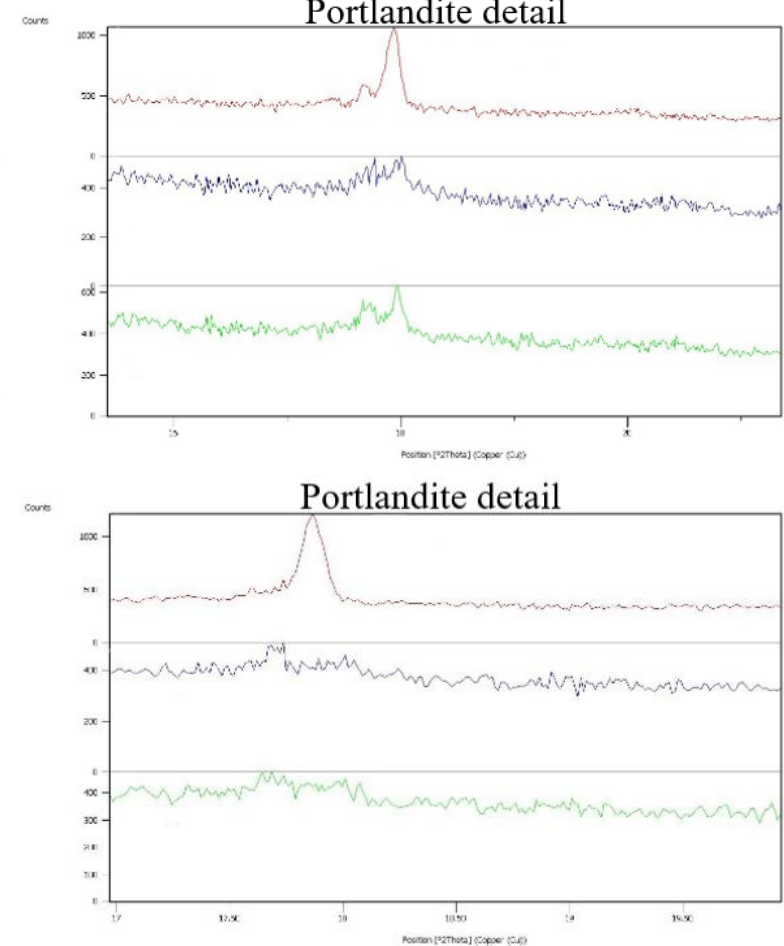

It can be seen from Figure 6 that there were more quartz and calcite peaks in all of the mixtures than portlandite peaks. A portlandite peak was seen at $2 \theta=18^{\circ}$ in the ref. specimens exposed to $20 \circ \mathrm{C}$. However, after the exposure to 700 으 and the cooling regimes, the XRD analysis showed no diffraction peak for portlandite. According to the XRD results, there was no difference between the concrete mixtures.

Conclusions

In this study, the compressive strengths of concrete specimens containing chemical admixtures were determined after being exposed to high temperatures and cooling regimes, namely air cooling and water cooling. The experimental tests were carried out on four concrete mixtures: ref mixture (concrete without an admixture), $\mathrm{P}$ mixture (concrete with 
plasticizer), A mixture (concrete with antifreeze) and PA mixture (concrete with plasticizer+antifreeze). Within the scope of this study water absorption, UPV and compressive strength tests were conducted at the temperatures of 20, 200, $400,550,700^{\circ} \mathrm{C}$. The results obtained in this study are as follows:

- The highest compressive strength was obtained for the PA concrete mixture at $20{ }^{\circ} \mathrm{C}$. The water absorption and UPV test results of this mixture were also in support of the compressive strength results.

- The water absorption categories of all of the concrete mixtures increased with the increase in temperature above 200 ㅇ C for both cooling regimes. According to the differences in the water absorption capacities, the air cooled specimens were more damaged than the water cooled ones.

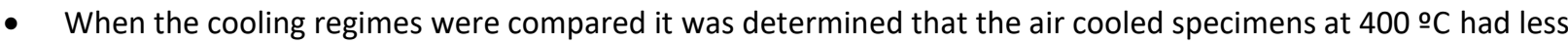
damage compared to the water cooled ones. On the other hand, when temperatures reached 550 and $700 \stackrel{\circ}{ } \mathrm{C}$, the water cooled specimens showed better resistance.

- The concrete type that suffered the least damage at 550 and $700{ }^{\circ} \mathrm{C}$ was the water cooled $\mathrm{A}$ concrete mixture. The compressive strength decrease of the $A$ concrete mixture was $55.51 \%$ at the maximum temperature.

- The concrete type most damaged at 550 and $700 \stackrel{\circ}{ } \mathrm{C}$ was the air cooled PA concrete mixture. A $74.41 \%$ decrease was observed in the strength of this mixture at the maximum temperature.

- When the $\mathrm{pH}$ of cooling water was examined, it was found that the highest $\mathrm{pH}$ difference was for the PA concrete mixture at all temperatures.

- Total weight loss is about $39 \%, 40 \%, 41 \%$ and $42 \%$ for Ref., P, A and PA concrete, respectively according to TGA.

- XRD patterns for all of the concrete mixtures were similar. After being exposed to $700{ }^{\circ} \mathrm{C}$ and the cooling regimes, the XRD analysis showed no diffraction peak for portlandite.

References

Afzal M. T. \& Khushnood, R.A. (2020). Influence of carbon nano fibers (CNF) on the performance of high strength concrete exposed to elevated temperatures. Construction and Building Materials, Article in press https://doi.org/10.1016/j.conbuildmat.2020.121108

Ahmad, A.H. \& Abdulkareem, O.M. (2010). Effect of high temperature on mechanical properties of concrete containing admixtures. Al-Rafidain Engineering, 18, 43-54.

Alharbi, Y.R., Abadel, A.A., Elsayed, N., Mayhoub, O. \& Kohail, M. (2020). Mechanical properties of EAFS concrete after subjected to elevated temperature. Ain Shams Engineering Journal, Article in press https://doi.org/10.1016/j.asej.2020.10.003

Aruntaş, H.Y. Durmuş, G. Can, Ö. \& Gökçe, H.S. (2009). Yüksek sıcaklık etkisinde kimyasal katkılı betonların incelenmesi. $3^{\text {rd }}$ chemical admixtures for structures symposium and exhibition, Ankara.

ASTM C 494. (2004). Standard specification for chemical admixtures for concrete. Concrete and mineral aggregates. Annual Book of ASTM Standards. Philadelphia, USA

ASTM C 597-83. (2016). Standard Test method for Pulse Velocity through Concrete. Annual Book of ASTM Standards. Philadelphia, USA.

ASTM C 642. (2004). Standard test method for density, absorption, and voids in hardened concrete. Annual Book of ASTM Standards. Philadelphia, USA.

AzariJafari, H., Amiri, M.J.T., Ashrafian, A., Rasekh, H., Barforooshi, M.J. \& Berenjian, J. (2019). Ternary blended cement: an ecofriendly alternative to improve resistivity of high-performance self-consolidating concrete against elevated temperature. Journal of Cleaner Production, 223, 575-586 https://doi:10.1016/j.jclepro.2019.03.054

Beatriz da Silva, J., Pepe, M. \& Toledo Filho, R. D. (2020).High temperatures effect on mechanical and physical performance of normal and high strength recycled aggregate concrete. Fire Safety Journal, 117, 103222 https://doi.org/10.1016/j.firesaf.2020.103222

Benaicha, M., Jalbaud, O., Alaoui, A.H. \& Burtschell, Y. (2015). Correlation between the mechanical behavior and the ultrasonic velocity of fiberreinforced concrete. Construction and Building Materials, 101, 702-709.

Caetano, H., Ferreira, G., Rodrigues, J.P.C. \& Pimienta, P. (2019). Effect of the high temperatures on the microstructure and compressive strength of high strength fibre concretes. Construction and Building Materials, 199, 717-736. https://doi.org/10.1016/j.conbuildmat.2018.12.074

Dexing, L., Enyuan, W., Xiangguo, K., Shuai, Z., Yanhui, K., Xiaoran, W., Dongming, W. \& Quanlin, L. (2018). Mechanical properties and electromagnetic radiation characteristics of concrete specimens after exposed to elevated temperatures. Construction and Building Materials, 188, 381-390. https://doi.org/10.1016/j.conbuildmat.2018.07.236

Durgun, M.Y. \& Sevinç, A.H. (2019). High temperature resistance of concretes with GGBFS, waste glass powder, and colemanite ore wastes after different cooling conditions. Construction and Building Materials, 196, 66-81.

Gökçe, H.S. (2019). High temperature resistance of boron active belite cement mortars containing fly ash. Journal of Cleaner Production, 211, 9921000 https://doi.org/10.1016/j.jclepro.2018.11.273

Hiremath, P.N. \& Yaragal, S.C. (2018). Performance evaluation of reactive powder concrete with polypropylene fibers at elevated temperatures. Construction and Building Materials, 169, 499-512. https://doi.org/10.1016/j.conbuildmat.2018.03.020 
Hwang, E., Kim, G., Choe, G., Yoon, M., Gucunski, N. \& Nam, J. (2018). Evaluation of concrete degradation depending on heating conditions by ultrasonic pulse velocity. Construction and Building Materials, 171, 511-520. https://doi.org/10.1016/j.conbuildmat.2018.03.178

Karahan, O., Durak, U., İlkentapar, S., Atabey, İ. İ., \& Atiş, C. D. (2019). Resistance of polypropylene fibered mortar to elevated temperature under different cooling regimes. Revista de la Construcción. Journal of Construction, 18(2), 386-397.

Karakoç, M.B. (2013). Effect of cooling regimes on compressive strength of concrete with lightweight aggregate exposed to high temperature. Construction and Building Materials, 41, 21-25. http://dx.doi.org/10.1016/j.conbuildmat.2012.11.104

Khan, J. \& Kumar, G. (2020). Influence of binary antifreeze admixtures on strength performance of concrete under cold weather conditions. Journal of Building Engineering, 102055, Article in press https://doi.org/10.1016/j.conbuildmat.2020.121647

Lim. S. \& Mondal, P. (2015). Effects of nanosilica addition on increased thermal stability of cement-based composite. ACI Mater. Journal, 112(2), 305315.

Luo, X., Sun, W. \& Chan, S.Y.N. (2010). Effect of heating and cooling regimes on residual strength and microstructure of normal strength and highperformance concrete. Cement and Concrete Research, 30, 379-83.

Maanser, A., Benouis, A. \& Ferhoune, N. (2018). Effect of high temperature on strength and mass loss of admixtured concretes. Construction and Building Materials, 166, 916-921. https://doi.org/10.1016/j.conbuildmat.2018.01.181

Mehdipour, S., M. Nikbin, I.M., Dezhampanah, S., Mohebbi, R., Moghadam, H., Charkhtab, S. \& Moradi, A. (2020). Mechanical properties, durability and environmental evaluation of rubberized concrete incorporating steel fiber and metakaolin at elevated temperatures. Journal of Cleaner Production, 254, 120126 https://doi.org/10.1016/j.jclepro.2020.120126

Papachristoforou, M., Anastasiou, E.K. \& Papayianni, I. (2020). Durability of steel fiber reinforced concrete with coarse steel slag aggregates including performance at elevated temperatures. Construction and Building Materials, 262, 120569 https://doi.org/10.1016/j.conbuildmat.2020.120569

Plank, J., Sakai, E., Miao, C.W., Yud, C. \& Hong, J.X. (2015). Chemical admixtures - Chemistry, applications and their impact on concrete microstructure and durability. Cement and Concrete Research, 78, 81-99. http://dx.doi.org/10.1016/j.cemconres.2015.05.016

Polat, R. (2016). The effect of antifreeze additives on fresh concrete subjected to freezing and thawing cycles. Cold Regions Science and Technology, 127, 10-17 https://doi.org/10.1016/j.coldregions.2016.04.008

Salahuddin, H., Nawaz, A., Maqsoom, A., Mehmood, T. \& Zeeshan, B.A. (2019). Effects of elevated temperature on performance of recycled coarse aggregate concrete. Construction and Building Materials, 202, 415-425. https://doi.org/10.1016/j.conbuildmat.2019.01.011

Su Tong, S., Yuqi, Z. \& Qiang, W. (2020). Recent advances in chemical admixtures for improving the workability of alkali-activated slag-based material systems. Construction and Building Materials, 121647, Article in press https://doi.org/10.1016/j.conbuildmat.2020.121647

TS 1247. (2018). Concrete mixing, casting and maintenance rules (under normal weather conditions). Turkish Standards Institute, Ankara, Turkey.

TS 802. (2016). Design of concrete mixes. Turkish Standards Institute, Ankara, Turkey.

TS EN 1008. (2003). Mixing water for concrete - Specifications for sampling, testing and assessing the suitability of water, including water recovered from processes in the concrete industry, as mixing water for concrete. Turkish Standards Institute, Ankara, Turkey.

TS EN 1097-6. (2013). Tests for mechanical and physical properties of aggregates- Part 6: Determination of particle density and water absorption. Turkish Standards Institute, Ankara, Turkey.

TS EN 12350-2. (2010). Testing fresh concrete - Part 2: Slump test. Turkish Standards Institute, Ankara, Turkey.

TS EN 12390-2. (2010). Testing hardened concrete- Part 2: Making, and curing specimens for strength tests. Turkish Standards Institute, Ankara, Turkey.

TS EN 12390-3. (2010). Testing hardened concrete - Part 3: Compressive strength of test specimens. Turkish Standards Institute, Ankara, Turkey.

TS EN 12504-1. (2011). Testing concrete in structures- Part 1: Cored specimens-Taking, examining and testing in compression. Turkish Standards Institute, Ankara, Turkey.

TS EN 197-1. (2012). Cement - Part 1: Composition, specification and conformity criteria for common cements. Turkish Standards Institute, Ankara, Turkey.

TS EN 206. (2017). Concrete - Specification, performance, production and conformity. Turkish Standards Institute, Ankara, Turkey.

TS EN 934-2. (2011). Admixtures for concrete, mortar and grout-Part 2: concrete admixtures - definitions, requirements, conformity, marking and labeling. Turkish Standards Institute, Ankara, Turkey.

Wang, W., Lu, C., Li, Y. \& Li, Q. (2017). An investigation on thermal conductivity of fly ash concrete after elevated temperature exposure. Construction and Building Materials, 148, 148-154. http://dx.doi.org/10.1016/j.conbuildmat.2017.05.068

Wang, Y., Liu, F., Xu, L. \& Zhao, H. (2019). Effect of elevated temperatures and cooling methods on strength of concrete made with coarse and fine recycled concrete aggregates. Construction and Building Materials, 210, 540-547. https://doi.org/10.1016/j.conbuildmat.2019.03.215 